\title{
The implementation of Moodle platform through lecturer's perspectives at English department
}

\author{
Tazkiyatunnafs Elhawwa \\ tazkiyatunnafs.elhawwa@gmail.com \\ State University of Semarang \\ Kampus Pascasarjana Jl. Kelud III Semarang, Jawa Tengah, Indonesia
}

Received: January 6, 2017; Accepted: September 26, 2017; Published: September 30, 2017

\begin{abstract}
Information and Communication Technology is now becoming an essential part of everyday life of most people in the world. This paper analyzed the main functionalities and tools available in the Moodle platform and their use through lecturer's perspectives at English Department of IAIN Palangka Raya. This study belongs to descriptive qualitative research. In the present study, teachers are expected to implement the Moodle platform of Information, Communication, and Technology (ICT) in EFL classes, and make the Moodle platform of ICT becoming a complement to conventional teaching in EFL classrooms, especially when developing listening, reading and writing skills in English. The results showed that the Moodle platform contains some of the main tools of the standard Moodle platform like assignments, chats, forums, news and quiz/survey. The most the student's purposes of the use of the Moodle platform were 'download materials', 'news' and 'deliver assignments', and the most used information materials are 'texts' and 'slides'.
\end{abstract}

Keywords: ICT, Moodle platform, EFL classroom, lecturer's perspectives

How to cite this paper: Elhawwa, T. (2017). The implementation of Moodle platform through lecturer's perspectives at English department. Journal on English as a Foreign Language, 7(2), 227-240.

Nowadays it is not possible to think about the teaching and learning process without associating it with the Information and Communication Technology (ICT). ICT plays an important role in education, having a special relevance in the instructional component, supported by Learning Management Systems,

Journal on English as a Foreign Language, 7(2), 227-240

Copyright @ 2017 by JEFL, p-ISSN 2088-1657; e-ISSN 2502-6615 
such as Moodle (Zainuddin, Idrus, \& Jamal, 2016). Moreover, these platforms have many capabilities provided that they are used in their fullness.

Zainuddin, Idrus, and Jamal (2016) added that ICT is now becoming an essential part of everyday life of most people in the world. From the smooth running of vital functions, such as banking and finance, to social networking and education, new technologies rapidly transform very important aspects of our life. ICT empowered us to perform tasks that were inconceivable only a few decades ago. From our personal computers, we can buy and sell all kinds of products, keep in touch with friends and find new insight in teaching EFL classes, participate in chat rooms and discussion group forum. To conclude, ICT, the internet, and modern technology is on the forefront of language teaching offering teachers and students alike the opportunity to explore and even exploit English in ways that were not possible before.

About the role of ICT in EFL class, nowadays, students and teachers are strongly expected to be using ICT in EFL class. In the future curriculum "the ability to use digital tools" is defined as a basic skill along with numeracy, the ability to express oneself orally, to read and write. ICT used by teachers has been under investigation for a long time for two basic reasons: to find the barriers in the way of successful integration of technology into the curriculum (Hew \& Brush, 2007) and to take suitable actions in order to include courses of training teachers in modern technologies (Paraskeva et al., 2008). Here, knowledge of English can be a contributing factor to ease of technology use, perceived ease of use, positive attitudes, and even purchasing computers.

Fosnot and Perry (2005) stated in teacher's perspectives, from the cognitive constructivist perspective, learning normally starts by observing or experiencing, and then continue with making meaning and relating current experiences to cognitive systems which learners have already developed. Learners then integrate or differentiate the new knowledge, and a new balance (accommodation) in their cognitive system is formed. Also in line with Fosnot and Perry, in this technological revolution and the information age, using technology in teaching English becomes "a fact of life" (Chapelle, 2001, p. 1) and becomes "a part of the broader ecology of life at the turn of the century" (Warschauer \& Meskill, 2000, p. 10). Here, using technology in daily life is one of the important components.

Furthermore, with all of the technological advances that are presented nowadays, ICT is becoming more important in the teaching-learning process in 
the L2 language classroom. There is no doubt that the role of the teacher is important in the process of integrating ICT into the EFL classroom. Moreover, offering constant training to teachers is very crucial in that they should adapt themselves to the changing society, emerging technologies, and new learning and teaching environment.

An effective way of ICT in English language teaching classrooms depends on many of factors. One of the important factors is the teachers' knowledge and skills in using ICT in class. According to Hew and Brush (2008), three types of knowledge and skill can create major barriers to ICT used by teachers, they are the lack of specific technical knowledge and skills (Snoeyink \& Ertmer, 2001), and technology-supported pedagogical knowledge and skills (Hughes, 2003).

There are also some related studies dealing with ICT in EFL classes. Nikolova (2003) as cited in Hsieh (2009) states that numerous studies suggest that computerized media and a multimedia environment can be helpful for learning foreign language vocabulary. However, the materials in the studies have mainly been commercial or teacher-produced. Student authoring in computer-based material designed for foreign language learning has been shown to enhance vocabulary learning. It has been asserted that online debate is an excellent medium for generating social construction of knowledge.

In line with this, Elia, (2007) states that ICT plays a part in fostering intercultural competence, which is a part of learning a second or foreign language. ICT provides a variety of different approaches as well as learning styles that reinforce the material delivered in other formats. Enjoyment is very much a part of effective learning, thereby captivating learners' interest, increasing personal discovery, generating enthusiasm and the desire to learn thereby instilling an interest from within to improve the learners' motivation. Also, Jarvis (1998) believes that by integrating basic IT skills in the EFL classroom, we are developing language skills and equipping learners with technology skills. The applications of these technology skills go beyond the EFL. Here, in my opinion, the system is based on the concepts of social constructivism which tries to offer both educators and students a platform for online interaction and collaboration. Moodle, developed specifically for teaching, can provide a variety of different teaching activities for students, allow students to take full advantage of modern network technology to exchange ideas and obtain learning experience and build personal knowledge system.

Journal on English as a Foreign Language, 7(2), 227-240

Copyright @ 2017 by JEFL, p-ISSN 2088-1657; e-ISSN 2502-6615 
According to Chesapeake and He (2004), the menu to implement the Moodle platform is as follows. First is Assignments. Assignments allow the teacher to specify a task that requires students to prepare digital content (any format) and submit it by uploading it to the server. Typical assignments include essays, projects, reports and so on. This module includes grading facilities. It also allows teachers to collect work from students; to evaluate the student's work and provide feedback including grades, in a private mode. It allows students to upload assignment files and to submit their work via an online text.

Second is Discussion Boards (Forums). Forums can be structured in different ways and can include peer rating of each posting. The postings can be viewed in a variety of formats and can include attachments. By subscribing to a forum, participants will receive copies of each new posting in their email. A teacher can impose subscription on everyone if they want to (Chesapeake \& He, 2004).

The third is Live Chat. The Chat module allows participants to have a real-time synchronous discussion via the web. This is a useful way to get a different understanding of each other and the topic being discussed. The mode of using a chat room is quite different from the asynchronous forums. The Chat module contains a number of features for managing and reviewing chat discussions (Chesapeake \& He, 2004).

Fourth is Content Delivery (Lesson). A lesson delivers content in an interesting and flexible way. It consists of a number of pages. Each page normally ends with a question and a number of possible answers. Depending on the student's choice of answer they either progress to the next page or are taken back to a previous page. Navigation through the lesson can be straightforward or complex, depending largely on the structure of the material being presented (Chesapeake \& He, 2004).

Last is Journal. The teacher asks the student to reflect on a particular topic, and the student can edit and refine their answer over time. This answer is private and can only be seen by the teacher, who can offer feedback and a grade on each journal entry (Chesapeake \& He, 2004).

Based on the background above, this paper explores about evaluating the implementation of the Information, Communication, and Technology (ICT) through lecturer's perspectives in EFL class in English Department at IAIN Palangka Raya and the main functionalities and tools available in the Moodle 
platform. However, the purpose of this project is to evaluate the implementation of ICT in EFL class in English Department at IAIN Palangka Raya through lecturer's perspective as a complement to conventional teaching in EFL classrooms.

This project was developed to both lecturers and students of English Department at IAIN Palangka Raya. They are expected to implement the Moodle platform of ICT in EFL classes, and make the Moodle platform of ICT becoming a complement to conventional teaching in EFL classrooms, especially when developing reading, writing and listening skills in English.

The framework is done to arrange the plot of the idea. This article begins with the introduction clarifying on the importance of ICT in EFL classes. The purpose and goal are determined to specify the topic to be discussed. The purpose is to evaluate the implementation of Moodle platform in EFL class in English Department at IAIN Palangka Raya as a complement to conventional teaching in EFL classrooms. Previous researches and theoretical perspectives are presented according to the degree to which they are vital for an understanding of the topic. Next, the theoretical frameworks are accounted for. Here, the theory underlining ICT and the previous study are discussed together in order to have a complete insight of the Moodle platform of ICT. The possible constraints may face difficulties during the implementation are done. Then evaluation, analysis, and discussion are done after the implementation through lecturer's perspective.

\section{METHOD}

This study belongs to descriptive qualitative research. Here, the participants are the teachers and students of English Department of IAIN Palangka Raya. This study focuses on the implementation of Moodle through lecturer's perspective. Here, the researcher observes the EFL learning process during the implementation of Moodle platform of Information, Communication, and Technology (ICT) especially when developing reading, writing, and listening skills in English.

\section{FINDINGS AND DISCUSSION}

Moodle is a management system of learning which can record the process of learners' activities online and this may supervise students to work harder. The blended learning calls for learners' sufficient preview and review, and they need to do the extensive exercise of reading, writing, listening and translation. It requires learners to finish tests online, make self-evaluation, have 
a group discussion and write feedbacks. Their abilities of independent learning could be well developed in the course.

Moodle is a free and open-source software learning management system. Developed on pedagogical principles, Moodle is used for blended learning, distance education, flipped classroom and other e-learning projects in schools, universities, workplaces and other sectors. With customizable management features, it is used to create private websites for online courses for educators and trainers to achieve learning goals. Moodle allows for extending and tailoring learning environments using the community-sourced plugin. The learning process seems to have been constructivist in nature since students found relevant information and put it together for a presentation on their websites. A teacher working within the framework similarly have to be constructivist in his / her approach to teaching since Moodle provides the framework in but each teacher would have to prepare the groundwork for the specific content area EFL class. To sum up, it is possible to recommend the Moodle as a framework for project-based work in the EFL classroom. It provides opportunities for learners throughout the world to collaborate on projects that integrate technology meaningfully into their learning. Although the Moodle framework clearly requires a lot of work on the part of the teacher, it represents a way for EFL learners to engage in authentic materials in EFL class.

To develop the ICT in EFL class in IAIN Palangka Raya, there are some procedures to be done. First, the dean socializes the importance of using ICT in EFL classes. This is done by holding a national or regional seminar on the importance of using ICT in EFL classes involving both lecturers and students. Here, some experts of big universities are invited to present a recent technology in EFL class. Second, the dean carries out the workshop on ICT in EFL classes to English lecturers. The workshop should cover the introduction to the Moodle platform, and how to implement Moodle platform in EFL classes. Third, the curriculum of EFL using Moodle platform of ICT is designed by the lecturers together with the experts. During the first half semester, the evaluation must be done to ensure that the ICT has been implemented in the EFL classes.

\section{The Possible Constraints May Face}

There have been some possible difficulties that may be faced by English Department at IAIN Palangka Raya in terms of implementing Moodle Platform of ICT into the EFL curriculum. The projects have been done as small-scale projects in order to introduce technology into the EFL classrooms. 
One of the problems is that the internet access is still not available in some areas of campuses. The internet can only be accessed in certain areas such as lecturer rooms, office room, laboratory, library, and rector office. However, the internet cannot be accessed in some areas such as student dormitory, lecturing rooms, and other public areas such as parking area, sports area, and canteen.

Another problem is that there is a limited broadband. In IAIN Palangka Raya, there are only 12 megabytes of broadband' and 6 megabytes is used for the server. In fact, there are only 6 megabytes used by 3.000 students to a dialup connection. The result is that the connection is not as fast as expected. The internet connection was slow to access. All of this affects the learning process using ICT based.

The other problem is that ICT is regarded as a new difficult thing for both lecturers and students. That is the technological problem. Some lecturers and students are not still familiar with using the Internet. Consequently, they are hard to follow the learning process using ICT. It needs much time to socialize the ICT in EFL classes to them. It is necessary to provide alternatives that can accompany teachers in designing virtual environments as support to face-to-face classes.

Based on the implementation of Moodle curriculum, there are several constraints faced by the lecturers. First, in terms of listening, the Moodle platform actually is a good alternative to offer listening materials. Moodle has plenty of modules for language learning. Chatting room, a module of Moodle, can be embedded as a platform for conducting the listening class. Here, Moodle provides EFL learners alternatives to get access to English materials. Moodle has a function of management that can record learners' learning time, which can help EFL teachers to monitor and supervise students' devotion to learning. During the course of learning EFL, online learning is more preferred to the listening exercise in the classroom. The problem is that the materials provided by the Moodle are hard to follow. The conversation is too fast so that the learners cannot listen well the content.

Second, in terms of speaking, Moodle actually provides the real experience of speaking. In blended learning of EFL, the speaking practice can be conducted in a regular classroom. The face-to-face communication can help learners understand others more easily. The teacher can also upload documents of relative background information, topic questions that are frequently used 
about the topic to the Moodle platform, which can help to arm the learners with more knowledge to use during talking. For those learners who are always too shy to open their mouth, the online chatting is another good choice. COVELL provides a free and powerful module developed to study foreign languages. It can be embedded in Moodle and works as a speaking platform for students to chat in English with their classmates or native English speakers all over the world. Again, in this case, both lecturer and learners get problems, such as some utterances are hard to follow; the talking is too fast, and so on.

Third, in terms of reading comprehension, actually, in the blended learning of EFL courses, the intensive reading is advised to be conducted in the regular classrooms, since the learners can better understand the reading materials and the teachers can also offer instant instructions to them. For the extensive reading, Moodle provides diverse and rich materials for learners to choose. The problems constrain by the learners are (a) there are some unfamiliar words; (b) difficult to mind map the texts; and (c) no local authentic materials available.

Fourth, in terms of writing, Moodle is designed with some functions for writing practice. The functions of the forum, workshop, and wiki offer enough space for EFL learners to practice writing. A forum is a good place for students to have a brainstorming of topics, contents, and structures before starting writing. The function of workshop allows both the instructors and students to read others' writings and evaluate them. This way of evaluation not only allows students to find out the problems in their own writing but also offer them chances to learn from others. The most prominent aspect of the course is to guide EFL learners to focus more on the process of writing rather than the result of writing. Here, the learners face a number of problems such as (1) Moodle do not provide students' handwriting product so that it is hard for the teachers to see the students' handwriting products; and (2) Moodle does not provide writing score guidelines so that it is difficult for the teacher to score directly the students' writing product.

\section{Evaluation through Lecturer's Perspective}

Based on the lecturer's experience on the implementation the Moodle platform of Information, Communication, and Technology (ICT) in English Department of IAIN Palangka Raya is a complement to conventional teaching in EFL classrooms, there are some evaluations to be done related to Moodle curriculum in teaching language skills. The Moodle platform is not specifically geared to the learning and teaching of EFL, but it integrated appropriately into 
the EFL class program. It can be an ideal way for EFL learners to learn English in a contextualized way. In this sense, involving learners in a Moodle platform project represents a realization of the visions of the English department curriculum where English is taught and learned as a foreign language in order to achieve proficiency in four domain skills (social interaction, access to information, presentation and appreciation of literature and culture, and language).

Based on the implementation of Moodle in EFL classes at IAIN Palangka Raya, there are some evaluations to be noted. First, the curriculum including lesson plan and time allocation still do not include the Moodle platform. Consequently, the lecturers get difficulties in implementing Moodle in EFL class. Moodle platform is seen as teaching media outside the EFL curriculum. In fact, there will be easy for the lecturer if EFL curriculum and Moodle platform are integrated together. Therefore, inserting Moodle platform intro EFL curriculum will be the best alternatives for next semester in EFL classes. In addition, by implementing Moodle platform, it is enabling for the lecturers to teach four language skills: listening, reading, speaking and writing in integrative ways.

Second, in terms of human resources, both teachers and students still consider that Moodle is not easy to be implemented. Some of them are not familiar with such learning tools. They do not know to operate such technologies. Consequently, the EFL class will face several problems such 'blind' technology in EFL classroom, the technology facility cannot be optimized, and so forth. Therefore, it is recommended that the campus carry out a workshop on Moodle for both lecturers and students. The workshop should emphasize on the capability of using Moodle platform in EFL class.

Third, since using Moodle in EFL class needs the new design in teaching scenario. It is needed new lesson plans and EFL curriculum. Therefore, it is recommended that the lecturers provide lesson plans for each subject using Moodle platform. The workshop on making lesson plan using Moodle platform is strongly recommended.

Fourth, teaching EFL using Moodle platform needs some high technological tools such as internet connection, laptops, and so on. Without such tools, the implementation of Moodle platform in EFL class is nothing, since applying Moodle platform in EFL class needs an internet connection. Therefore, it is recommended that the class should provide such tools 
immediately. The bandwidth for internet connection should be provided higher so that internet connection can be easily done. Up till know, IAIN Palangka Raya has 12 bandwidths for covering all units. 6 of 12 bandwidths is used for data serving, while the rest of them is used for all units. This is not very adequate. To run the Moodle platform well for lecturing activity, the bandwidth should be increased up to 40 bandwidths.

The main aim of the project was to evaluate the implementation the Moodle platform of Information, Communication and Technology (ICT) in EFL class in English Department at IAIN Palangka Raya from the lecturer's perspective. The result was that students were positively motivated when they were taught using Moodle. EFL learners were committed and the amount of time spent on-task in the lesson was much higher than in the ordinary EFL classroom environment. After a little extra guidance, EFL learners found the exercises stimulating and rewarding. It was very pleasing to see EFL learners hard at work.

However, there are some suggestions to be noted. First, the EFL curriculum should include Moodle platform into EFL curriculum. Second, the campus should carry out a workshop on Moodle for both lecturers and students on using Moodle platform in EFL class. Third, the lecturers should provide lesson plans for each subject using Moodle platform. Fourth, bandwidth for internet connection should be provided higher so that internet connection can be easily done. To run the Moodle platform well for lecturing activity, the bandwidth should be increased up to 40 bandwidths.

The Moodle platform is characterized by a set of functionalities grouped in two different classes: resources and modules. Resources represent instructional materials that are usually created in digital formats and then uploaded to the platform. Web pages, PowerPoint files, word documents, flash animations, video and audio files represent some examples of these resources. Modules are components created via Moodle in order to provide interaction among students and teachers towards manipulation and content transformation. In this context, the Moodle platform provides several base, Lessons, Assignments, Workshops, Chats, Forums, News, Glossary, Wikis, Choice, Quiz, Survey, Feedback, SCORM (Shareable Content Object Reference Model) and External tools. Regarding the activities of the learning platforms, it presents a classification based on six classes: Creation, Organization, Delivery, Communication, Collaboration, and Assessment. 
The Moodle platform can include diverse forms of language learning materials. The pictures, audio, and video files can make learners feel like being in authentic foreign language surroundings, which can booster their interest in learning EFL. Moodle also offers more space and ways for ESL learners and their teachers to communicate, which helps learners better catch their teachers' intention and facilitate teachers to obtain learners feedback of teaching.

\section{CONCLUSION}

This paper analyses the main functionalities and tools available in the Moodle platform and their use at English Department of IAIN Palangka Raya. It was found that the Moodle Platform contains some of the main tools of the standard Moodle platform like Assignments, Chats, Forums, News and Quiz/Survey. The analysis of the students' response to the applied questionnaire revealed that the most mentioned purpose of the use of the Moodle were 'Download materials', 'News' and 'Deliver assignments' and that the most used information materials are 'Texts' and 'Slides'. Additionally, students gave more importance to 'News' and 'Assignments'. Besides, it can be noticed that students that use the tools typically assign more importance to them. It can also be noted that it is enabled for students to get the interaction, the collaboration, and the real-time communication. To overcome the constraints, it should be taken into account that the successful use of e-learning platforms in the teaching and learning context critically depends on the teachers having knowledge about the tools, being aware of how they should be used and is capable of organizing all the communication process. As future work, it is considered important to perform a careful analysis of the underlying reasons for the use of the e-learning tools by the academic community, as well as to investigate on how these tools can help on promoting the success of EFL teaching and learning process. It is believed that Moodle platform is useful in EFL learning environments as proved for other EFL classes, teaching, and professional training environments.

The development of modern educational technologies makes it feasible to conduct blended learning, which response to the diversification of EFL teaching resources. The online environment is suitable for EFL learners' selfteaching, but with some limitations. Meanwhile, the majority of learners call for teachers' face-to-face instructions. The blended learning is a combination of online learning and offline learning, a mixture of individual-centeredness and group learning, a blending of traditional textbooks and multimedia, which can exploit teachers' roles of organizing, cooperating, instructing and the learners' roles of self-controlling, motivation. Inevitably, a lot of difficulties still remain 
to be settled when blended learning is practiced. It requires more commitment of learners, more devotion, and knowledge of teachers and more integration of traditional courses and modern technologies.

Although the Moodle platform proved to be a great success, it is clear that some basic principles have to be respected if both teachers and students are to remain motivated. Therefore, it is recommended that the teacher check beforehand that the network and software are working; consider EFL learners' previous ICT experience; introduce the purpose and objectives of the lesson; match the task to their abilities, ensuring that it is adequately challenging but not too difficult; monitor their work to ensure that they remain on task; and allow enough time at the end to review the EFL learners' progress.

\section{REFERENCES}

Chesapeake, \& He, K. (2004). Blending learning and the development of educational technology theory. Educational Technology of China, 3, 5-14.

Elia. (2007). Fables and ICT: Intercultural communication and e-language teaching.

Fosnot, C. T., \&, Perry, R. S. (2005). Constructivism: A psychological theory of learning. In Fosnot, C. (Ed.) Constructivism. Theory, perspectives, and practice (pp. 8-38) (2 $2^{\text {nd }}$ Ed.). New York: Teachers College Press.

Hew, K. F. \& Brush, T. (2007) “Integrating technology into K-12 teaching and learning: Current knowledge gaps and recommendations for future research. Education Technology Research Development, 55, 223-252.

Hsieh, P. (2009). The effects of computer communication by a course management (Moodle) on EFL Taiwanese students' English reading achievement and perception. La Sierra: La Sierra University Dissertation Department.

Hughes, A. (2003). Testing for language teachers. Cambridge: Cambridge University Press.

Jarvis, H. A. (1998). A role for information technology in the EFL classroom. CALL Review, IATEFL.

Paraskeva, F., et al. (2008). Individual characteristics and computer self-efficacy in secondary education teachers to integrate technology into educational practice. Computers \& Education: Elsevier Ltd., 1084-1091.

Snoeyink, R., Ertmer, P. (2001). Thrust into technology: How veteran teachers respond. Journal of Educational Technology Systems, 30(1), 85-111.

Warschauer, M., \& Meskill. (2000). The death of cyberspace and the rebirth of CALL. English Teachers' Journal, 53, 61-67. Retrieved from http://www.gse.uci.edu/markw/cyberspace.html 
Zainuddin, N., Idrus, R. M., \& Jamal, A. F. M. (2016). Moodle as an ODL teaching tool: A perspective of students and academics. The Electronic Journal of e-Learning, 14(4), 282-290.

\section{Author's Brief CV}

Tazkiyatunnafs Elhawwa was born in Pasuruan East Java on July 5, 1992. She was graduated from English Study Program of STAIN Palangka Raya. In September 2013, she was accepted at English Language Teaching Program of Graduate Program of UNISMA. Right now, she continues to S3 program in English Education in the State University of Semarang. 
The implementation of Moodle platform through lecturer's perspectives at English department Tazkiyatunnafs Elhawwa 